\title{
Effect of Maternal Disease and Antepartum Hemorrhage on Asphysia
}

\author{
Sumarni Sumarni ${ }^{{ }^{*}}$, Fitria Prabandari ${ }^{1}$, Juni Sofiana ${ }^{1}$ \\ ${ }^{1}$ Faculty of Health, Universitas Muhammadiyah Gombong \\ *corresponding author: sumarni2880@gmail.com
}

ARTICLE INFO

Article history

Received 13/12/2021

Revised 17/01/2022

Accepted 20/01/2022

Keywords

Antepartum hemorrhage

Asphyxia

Maternal disease

\begin{abstract}
Background: One of the causes of infant mortality is asphyxia of 26.5\% percent of infant mortality in Central Java Province in 2019. Factors associated with the occurrence of asphyxia neonatorum are maternal disease, antepartum hemorrhage (placenta previa, placental abruption), prolonged labor and infant less months (premature). Disease factors, especially hypertension, heart disease and diabetes mellitus will be related to the oxygen supply to the baby. The objective: to determine the effect of maternal disease and antepartum hemorrhage on asphyxia in newborns at Prof. Dr. Margono Soekarjo Hospital Purwokerto. Method: This type of research used an analytical observational method with a case control approach. The population in this study were all newborns at Prof. Dr. Margono Soekardjo Hospital July-December 2020 as many as 749 . The sample used was 150 with 75 samples for cases and 75 samples for control. The analytical method in this study uses Chi square. Results showed that maternal disease had a 4.8 times effect on asphyxia $(p=0.00495 \% \mathrm{Cl}$; OR $=4.8)$, placenta-previa had 5.2 times effect on asphyxia in newborns $(p=$ $0.002,95 \% \mathrm{Cl}$; OR $=5.2$ ), and placental abruption had an effect on asphyxia $(p=0.002)$. Conclusion: Factors that influence the incidence of asphyxia in newborns are maternal disease (hypertension, heart and diabetes mellitus), antepartum hemorrhage (placenta previa, placental abruption).
\end{abstract}

\section{Introduction}

The Infant Mortality Rate (IMR) and Toddler Mortality Rate (AKABA) are still a priority in Central Java. IMR achievements in 2020: 7.79/1000 KH and AKABA 8.99/1000 KH) although this figure is much better than the national target (IMR: 24/1,000 KH), however, IMR achievements have decreased compared to IMR achievements in 2019 (IMR: 8.24/1000 KH and AKABA 9.65/1000 KH, the achievement has exceeded the 2019 target), but the IMR is an indicator to see the health and welfare of the community in an area/country. In addition, the SDGs target has not been achieved (end of 2030 $<70)$. [1]

One of the causes of infant mortality is asphyxia by $26.5 \%$ percent of infant deaths in Central Java Province in 2019.[2] Asphyxia is a condition in which a baby cannot breathe spontaneously and regularly immediately after birth. Asphyxia is usually accompanied by hypoxia, hypercapnia and acidosis. When this process takes place it can result in brain damage or death. Asphyxia can also be related to the functions of other vital organs[3] Complications due to asphyxia are disorders of heart function that have been protracted resulting in neonatal shock, so that blood flow to the brain will decrease, this situation will cause hypoxia and brain ischemia which results in brain edema, this can also cause cerebral hemorrhage which can then lead to seizures and seizures. The next coma can result in death and if the baby is alive it can cause mental disability. [4]

The incidence of asphyxia in provincial referral hospitals in Indonesia, deaths due to asphyxia is $41.94 \%$. Asphyxia in newborns contributes $45 \%$ as a cause of infant mortality[5] The main causes of newborn or neonatal death in Indonesia include $29 \%$ premature babies, $25 \%$ sepsis and pneumonia, 
and $23 \%$ of newborns with asphyxia and trauma. Asphyxia in newborns occupies the 3rd cause of infant mortality in the world in the early period of life[5] According to Saifuddin the

factors associated with the occurrence of neonatal asphyxia are maternal and preterm (premature) diseases [4], while according to Mochtar these include placenta previa, placental abruption and prolonged labor[6]

Maternal diseases that can increase the risk of asphyxia include hypertension, heart disease and diabetes mellitus. In women with severe hypertension, placental abruption (premature detachment of the placenta) occurs more often, which causes the supply of oxygen and nutrients to be cut off to the fetus so that the fetus can die. In patients with heart disease, the process of straining causes disruption of the absorption of oxygen through the mother's lungs so that the amount of oxygen that reaches the fetus is reduced.

In hypertension in pregnancy (eg preeclampsia) high blood pressure causes reduced blood delivery to the placenta. this will definitely reduce the supply of oxygen and food for the baby. As a result, the baby's development becomes slow, and intrauterine hypoxia occurs, even more fatal, this disease can cause the placental tissue to suddenly detach from the uterus prematurely. [7] The effect of hypoxia is asphyxia neonatorum. The inability of the baby after birth to breathe normally due to disturbances in the exchange and transport of oxygen from the mother to the fetus so that there is a disturbance in the availability of oxygen and the expulsion of carbon dioxide. ${ }^{|1|}$ Pregnant women with a diagnosis of hypertension in pregnancy, this is in line with research conducted by Anggraini et al which shows that there is a relationship between hypertension in pregnancy and asphyxia neonatorum[8]

Research conducted by Ayuk Windiani, et al also stated that hypertension in pregnancy affects neonatorum asphyxia. In this study, it was found that newborns with asphyxia neonatorum who were born to mothers who had hypertension during pregnancy in Wonosari Hospital were $87 \%$ of the total research subjects. In women with hypertension during pregnancy, vascular constriction causes resistance to blood flow and plays a role in the development of arterial hypertension. In preeclampsia, impaired placental function due to decreased blood supply can result in fetal hypoxia. The effect of hypoxia is the occurrence of neonatorum asphyxia due to impaired oxygen exchange and transportation from the mother to the fetus, so that there is a disturbance in oxygen supply and carbon dioxide expenditure.[9] Another study was also conducted by Evi Desfauza which stated that there was a significant relationship between hypertension in pregnancy and neonatal asphyxia [10]

Meanwhile, in patients with diabetes mellitus, babies born to people with diabetes have a risk of suffering from asphyxia. The results of Kurniawan and Wiwin's research show that gestational diabetes has an effect on Respiratory Distress Syndrome (RDS) this is because during the delivery process seizures occur in the mother caused by increased maternal blood pressure causing fetal distress. Diabetes in pregnancy can cause blood coagulation to increase which causes impaired cardiac performance and can lead to less or more oxygen supply to the fetus, resulting in respiratory distress in neonates. The mother's pancreas works extra to produce insulin but insulin can't control blood glucose, so high blood glucose crosses the placenta by giving high blood glucose levels to the baby, this can cause the baby's pancreas to work extra to produce insulin to get rid of blood glucose so that it can cause RDS [11]

\section{Materials and Method}

The type of research used is analytic observational research. using a retrospective case control approach. The type of data used in this study is secondary data. The population in this study were 749 infants consisting of 460 infants with asphyxia and 289 infants with normal asphyxia. the number of samples is at least $10-15 \%$ of the population size. So the sample used is 75 respondents. The sample as cases amounted to 75 (asphyxia) while 75 respondents were not asphyxia as controls. So that the number of samples used was 150 . The sampling procedure used simple random sampling. In this study, the research instrument used was a check list. The analytical method in this study uses Chi square.

\section{Results and Discussion}

\subsection{Results}


1. Maternal disease factors related to the incidence of asphyxia in newborns at Prof. Dr. Margono Soekarjo Hospital Purwokerto

Based on the results of the analysis in Table 1, it shows that the majority of mothers who suffer from illness during pregnancy experience asphyxia neonatorum, namely $16(80 \%)$. In this study, the number of mothers who had a history of the disease were 20 mothers, consisting of hypertension, 14 mothers, heart disease, 2 mothers, and diabetes mellitus, 4 mothers.

Based on the chi-square correlation analysis, the probability value (p) is 0.004 with a significance level of $5 \%(0.05)$. It can be stated that maternal disease factors are associated with the incidence of asphyxia in newborns at Prof. Dr. Margono Soekarjo Hospital Purwokerto in 2020. While the results of the Odd Ratio analysis showed a value of 4.8 (Cl 1.5-15.2) which means that a history of maternal disease causes asphyxia in newborns by 4.8 times compared to infants born to mothers who have no history of disease.

Table 1. Cross tabulation of maternal diseases related to the incidence of asphyxia in newborns at Prof. Dr. Margono Soekarjo Hospital Purwokerto

\begin{tabular}{|c|c|c|c|c|c|c|c|c|}
\hline \multirow[t]{3}{*}{ Maternal diseases } & \multicolumn{4}{|c|}{ Asphyxia } & & & \multirow[t]{3}{*}{$\mathbf{P}$} & \multirow[t]{3}{*}{ OR } \\
\hline & \multicolumn{2}{|c|}{ Yes } & \multicolumn{2}{|c|}{ No } & \multicolumn{2}{|c|}{ Total } & & \\
\hline & f & $\%$ & f & $\%$ & f & $\%$ & & \\
\hline Yes & 16 & 80 & 4 & 20 & 20 & 13.3 & 0,003 & 4.8 \\
\hline No & 59 & 45.4 & 71 & 54.6 & 130 & 86,7 & & (Cl 1.5-15.2) \\
\hline Total & 75 & 50 & 75 & 50 & 150 & 100 & & \\
\hline
\end{tabular}

2. Factors of placenta previa related to the incidence of asphyxia in newborns at Prof. Dr. Margono Soekarjo Hospital Purwokerto

Based on the results of the analysis in Table 2, it shows that the majority of mothers who experienced placenta previa gave birth to babies with asphyxia, namely $17(81 \%)$ of the 21 cases of placenta previa experienced by mothers. Based on the chi-square correlation analysis, obtained a probability value $(p)$ of 0.002 with a significance level of $5 \%(0.05)$, it can be stated that the placenta previa factor is associated with the incidence of asphyxia in newborns at Prof. Dr. Margono Soekarjo Hospital Purwokerto.

While the results of the Odd Ratio analysis show a value of $5.2(\mathrm{Cl} 1.6-16.3$, which means that mothers who have placenta previa have a 5.2 times risk of asphyxia in newborns compared to babies born to mothers who do not have placenta previa.

Table 2. Cross tabulation of placenta previa related to the incidence of asphyxia in newborns at Prof. Dr. Margono Soekarjo Hospital Purwokerto

\begin{tabular}{|c|c|c|c|c|c|c|c|c|}
\hline \multirow{3}{*}{$\begin{array}{l}\text { Plasenta } \\
\text { Previa }\end{array}$} & \multicolumn{4}{|c|}{ Asphyxia } & & & \multirow{3}{*}{$\mathbf{p}$} & \multirow{3}{*}{ OR } \\
\hline & \multicolumn{2}{|c|}{ Yes } & \multicolumn{2}{|c|}{ No } & \multicolumn{2}{|c|}{ Total } & & \\
\hline & $f$ & $\%$ & $f$ & $\%$ & $f$ & $\%$ & & \\
\hline Yes & 17 & 81 & 4 & 19 & 21 & 14 & & 5.2 \\
\hline No & 58 & 45 & 71 & 54 & 129 & 86 & 0,002 & (Cl 1.6-16.3) \\
\hline Total & 75 & 50 & 75 & 50 & 150 & 100 & & \\
\hline
\end{tabular}

3. Factors of placental abruption related to the incidence of asphyxia in newborns at Prof. Dr. Margono Soekarjo Hospital Purwokerto

Based on the results of the analysis in Table 3, it shows that the majority of mothers who experienced placental abruption gave birth to babies with asphyxia by 25 mothers $(73.5 \%)$ of all mothers who experienced placental abruption, namely 34 mothers. Based on the chi-square correlation analysis, the probability value $(p)$ is 0.002 with a significance level of $5 \%(0.05)$. Because the value is $0.002<0.05$, it can be stated that placental abruption affects the incidence of asphyxia in newborns at Prof. Dr. Margono Soekarjo Hospital Purwokerto. While the results of the Odd Ratio analysis show a value of $3.7(\mathrm{Cl} 1.5-8.5)$, which means that mothers who 
experience placental abruption are at risk of asphyxia in newborns by 3.7 times compared to babies born to mothers who do not experience placental abruption.

Table 3.Cross tabulation of the frequency of placental abruption associated with the incidence of asphyxia in newborns at Prof. Dr. Margono Soekarjo Hospital Purwokerto

\begin{tabular}{lcccccccc}
\hline & \multicolumn{9}{c}{ asphyxia } & \multirow{2}{*}{$\begin{array}{c}\text { Placental } \\
\text { abruption }\end{array}$} & \multicolumn{2}{c}{ Yes } & & No & \multicolumn{2}{c}{ Total } & & OR \\
\cline { 2 - 6 } & $\mathbf{f}$ & $\%$ & $\mathbf{f}$ & $\%$ & $\mathbf{f}$ & $\%$ & & \\
\hline Yes & 25 & 73.5 & 9 & 26.5 & 34 & 22,7 & & \\
No & 66 & 56.9 & 50 & 43.1 & 116 & 77,3 & 0,002 & 3.7 \\
\hline Total & 75 & 50 & 75 & 50 & 150 & 100 & & \\
\end{tabular}

\subsection{Discussion}

1. Maternal disease factors related to the incidence of asphyxia in newborns at Prof. Dr. Margono Soekarjo Hospital Purwokerto

Based on the chi-square correlation analysis, the probability value $(p)$ is 0.004 with a significance level of $5 \%(0.05)$. It can be stated that maternal disease factors are associated with the incidence of asphyxia in newborns at Prof. Dr. Margono Soekarjo Hospital Purwokerto in 2020. While the results of the Odd Ratio analysis showed a value of 4.8 (Cl 1.5-15.2) which means that a history of maternal disease causes asphyxia in newborns by 4.8 times compared to infants born to mothers who have no history of disease.

Maternal disease can cause asphyxia in newborns, this is because disease factors, especially hypertension, heart disease and diabetes mellitus will be related to the oxygen supply to the baby. Manoe VM, Amir I reseach showed that Risk factors for asphyxia in newborns consist of maternal factors, namely: infection (chorioamnionitis), toxemia/eclampsia, maternal chronic disease (hypertension, heart disease, kidney disease, lung disease and diabetes mellitus). During pregnancy, there will be changes in circulation that are influenced by hormones. Increased weight in the mother and the extra tissue needed for the fetus to grow and develop in the womb. Blood pressure will fall in the first 6 months of pregnancy, this happens because of a decrease in peripheral vascular resistance caused by stretching of smooth muscles by the hormone progesterone after 24 weeks blood pressure will continue to rise. This increase occurs along with the enlargement of the uterus and the size of the conceptus. [12] [13][14] [15]

This condition will cause the uptake of oxygen in the uterine blood too much during pregnancy, if the blood flow to the placenta is delayed, the oxygen and nutrients that will be delivered to the fetus will be reduced, so that it will slow down the growth and development of the fetus, and increase the risk during childbirth. Preeclampsia can occur because it is influenced by several factors, namely the old age of the mother because at the age of the old mother will experience a decrease in body functions due to the degeneration process. The process of degeneration in the mother's reproductive system results in impaired body functions making it easy to get pregnant. [16]

In women with hypertension during pregnancy, vascular constriction causes resistance to blood flow and plays a role in the development of arterial hypertension. In preeclampsia, impaired placental function due to decreased blood supply can result in fetal hypoxia. The effect of hypoxia is the occurrence of neonatorum asphyxia due to impaired oxygen exchange and transportation from the mother to the fetus, so that there is a disturbance in oxygen supply and carbon dioxide expenditure. From the 96 study samples, there were $71.9 \%$ pregnant women with a diagnosis of hypertension in pregnancy, this is in line with research conducted by Anggraini et al in 2014 which showed that there was a relationship between hypertension in pregnancy and asphyxia neonatorum. [8] [17][18]

Asphyxia can cause an imbalance in body temperature and hypothermia occurs. Hypothermia can cause constriction of blood vessels resulting in anaerobic metabolism, increasing oxygen 
demand, and resulting in hypoxaemia. If this happens, the body quickly uses energy to stay warm so that when it's cold, the baby needs more oxygen. Thus, hypothermia can result in reduced oxygen flow to tissues and the neonate will experience hypoglycemia. Hypoglycemia in neonates can occur if conditions are found such as inadequate maternal nutrition during pregnancy, excess insulin production in infants with diabetic mothers, severe hemolytic disease in neonates, congenital defects and congenital metabolic diseases, asphyxia, and liver disease[12]

Another study was also conducted by Husna at all, which stated that there was a significant relationship between hypertension in pregnancy and neonatal asphyxia[10] Another study that confirmed the relationship between hypertension in pregnancy and asphyxia neonatorum was conducted by Anggraini et al in 2014 with the results that there was a significant relationship between hypertension in pregnancy and asphyxia in newborns (p-value 0.000). [8] This is in accordance with Hashemi's research, In hypertension in pregnancy (eg preeclampsia) high blood pressure causes reduced blood delivery to the placenta. this will definitely reduce the supply of

oxygen and food for the baby[7] As a result, the development of the baby becomes slow, and intrauterine hypoxia occurs, even more fatal, this disease can cause the placental tissue to suddenly detach from the uterus prematurely. The effect of hypoxia is asphyxia neonatorum. The inability of the baby after birth to breathe normally due to disturbances in the exchange and transport of oxygen from the mother to the fetus so that there is a disturbance in the availability of oxygen and the expulsion of carbon dioxide. ${ }^{|3|}$ Hypertension in pregnancy was a relationship with asphyxia neonatorum. [8]' [17] [18]

Heart disease can also cause asphyxia. In patients with severe heart disease, an epidural anesthetic can be given to numb the lower spinal cord and so that the patient does not have to strain during labor. Straining causes disruption of oxygen absorption through the mother's lungs so that the amount of oxygen that reaches the fetus is reduced. Babies are born with the help of forceps or by cesarean section. In addition to hypertension and heart disease, diabetes mellitus can also cause babies to be born with asphyxia. Immediately after delivery, many sufferers do not need insulin. Women who had diabetes before pregnancy, after delivery their need for insulin decreased drastically, then gradually increased again after about 72 hours.

Babies born to diabetics have a risk of suffering from asphyxia, low blood sugar and calcium levels, jaundice and an increased red blood cell count. This disorder is temporary and can be treated. The results of this study are in accordance with research conducted by Muliawati, that mothers with a history of hypertension have a risk 11.9 times greater than without a history of hypertension[19] [20]

\section{Factors of placenta previa related to the incidence of asphyxia in newborns at Prof. Dr. Margono Soekarjo Hospital Purwokerto}

Based on the chi-square correlation analysis, obtained a probability value $(p)$ of 0.002 with a significance level of $5 \%(0.05)$, it can be stated that the placenta previa factor is associated with the incidence of asphyxia in newborns at Prof. Dr. Margono Soekarjo Hospital Purwokerto. While the results of the Odd Ratio analysis show a value of 5.2 (Cl 1.6-16.3, which means that mothers who have placenta previa have a 5.2 times risk of asphyxia in newborns compared to babies born to mothers who do not have placenta previa.

Complications in the mother that can cause asphyxia are pre-eclampsia and eclampsia, placenta previa, placental abruption, prolonged or obstructed labor, infection and post-term pregnancy. [4] Placenta previa can cause asphyxia. This is because the placenta is the root of the fetus to suck nutrients from the mother in the form of $\mathrm{O} 2$, amino acids, vitamins, minerals and other substances to the fetus and remove the products of fetal metabolism and CO2. Impaired gas exchange in the placenta will cause fetal asphyxia[21][22] [23]

The results of the study are in accordance with the theory put forward by Mochtar which states that placenta previa is a placenta that implants in the lower uterine segment and covers part or all of the internal uterine ostium. [6] The incidence of placenta previa is $0.4 \%-0.6 \%$. Bleeding from placenta previa accounts for approximately $20 \%$ of all cases of antepartum haemorrhage. Seventy percent of patients with placenta previa experience painless vaginal bleeding in the third trimester. 20 percent had contractions accompanied by bleeding, and 10 percent had an accidental diagnosis of placenta previa by ultrasound or examination of the fetus at term. Complications in the mother can cause anemia to shock, while in the fetus it can cause asphyxia neonatorum to fetal death in utero. The results of this study are in line with research conducted by Ardyana there is a relationship between placenta previa and the incidence of asphyxia neonatorum with $p$ value $=0.000$, there is a 
relationship between prolonged labor and the incidence of asphyxia neonatorum with $\mathrm{p}$ value $=$ 0.000 , and there is a relationship between umbilical cord entanglement with the incidence of asphyxia neonatorum with $p$ value $=0.000$. [24]

3. Factors of placental abruption related to the incidence of asphyxia in newborns at Prof. Dr. Margono Soekarjo Hospital Purwokerto

Based on the chi-square correlation analysis, the probability value $(p)$ is 0.002 with a significance level of $5 \%(0.05)$. Because the value is $0.002<0.05$, it can be stated that placental abruption affects the incidence of asphyxia in newborns at Prof. Dr. Margono Soekarjo Hospital Purwokerto. While the results of the Odd Ratio analysis show a value of 3.7 (Cl 1.5-8.5), which means that mothers who experience placental abruption are at risk of asphyxia in newborns by 3.7 times compared to babies born to mothers who do not experience placental abruption.

Placental abruption is the separation of the placenta from its normal implementation in the uterus before the fetus is born, this can cause disturbances to the mother and fetus. Premature detachment of the placenta causes blood to accumulate between the placenta and the uterine wall which can cause disturbances to the mother and fetus.[25] [26][27]Complications for the fetus depending on the extent of the detached placenta can cause mild neonatal asphyxia to fetal death in utero. In pregnancies complicated by abruption, it is possible that neonates experience chronic hypoxia that leads to underdevelopment even in the absence of prematurity. Hypoxia may also explain the elevated risk of poor outcomes even among term neonates. placental abruption factors can cause neonatal asphyxia. [28][29][30]

\section{Conclusion}

Based on the results of the study, it can be concluded that maternal disease (hypertension, heart disease and diabetes mellitus) and antepartum bleeding affect the incidence of asphyxia. It is hoped that from the results of this study pregnant women can prevent risk factors for asphyxia by conducting early health checks before pregnancy so that optimal treatment of the disease can be carried out.

\section{Declaration}

Acknowledgments: Thank you to the Muhammadiyah University of Gombong and Prof. Dr. Margono Soekarjo Hospital Purwokerto for supporting and facilitating this research.

Conflicts of Interest: The authors declared that there is no conflicts of interest in this research.

\section{References}

[1] Dinkes Provinsi Jateng, "Laporan Kinerja Instansi Pemerintah 2020," 2019. Accessed: Jan. 10, 2022. [Online]. Available: https://e-renggar.kemkes.go.id/file2018/e-performance/1030018-2tahunan-010.pdf

[2] Dinkes Provinsi Jateng, "Profil Kesehatan Provinsi Jawa Tengah Tahun 2019," Jawa Tengah, 2019. Accessed: Jan. 10, 2022. [Online]. Available: https://dinkesjatengprov.go.id/v2018/storage/2020/09/Profil-Jateng-tahun2019.pdf

[3] S. Prawirohardjo, Ilmu kebidanan. Edisi Ke 4, Cetakan Ke enam. , 4th ed., vol. 6. Jakarta: Yayasan Bina Pustaka Sarwono Prawirohardjo, 2020.

[4] A. B. Saifuddin, Buku Panduan Praktis Pelayanan Kesehatan Maternal dan Neonatal., vol. Cetakan ke 3. Jakarta: Yayasan Bina Pustaka Sarwono Prawirohardjo, 2014.

[5] Johariyah, "Hubungan antara Prematuritas, Berat Badan lahir, jenis persalinan dan kelainan kongenital dengan kejadian asfiksia di RSI Fatimah," Jurnal Kesehatan Ibu dan Anak, vol. 11, no. 2, Nov. 2017, Accessed: Jan. 10, 2022. [Online]. Available: https://ejournal.poltekkesjogja.ac.id/index.php/kia/article/view/32/26

[6] R. Mochtar, Sinopsis obstetri, obstetri fisiologi, obstetri patologi, 2nd ed., vol. 1. Jakarta: EGC, 2012.

[7] A. Hashemi, "Hubungan Paritas pada Penderita Pre-Eklampsia Berat terhadap Kejadian Asfiksia Neonatorum di RSD dr. Soebandi Kabupaten Jember (The Relation between Parity of Severe Pre-Eclampsia and Asphyxia Neonatorum Incidence at dr. Soebandi Hospital, Jember)," Jember, 2016. Accessed: Jan. 10, $2022 . \quad$ [Online]. Available: 
https://repository.unej.ac.id/bitstream/handle/123456789/71473/Ahmad\%20Hashemi.pdf?se quence $=1$ \&isAllowed $=\mathrm{y}$

[8] A. Anggraini, D. Yuliasari, and S. Susilawati, "Hipertensi pada Ibu Bersalin dengan Kejadian Asfiksia pada Bayi Baru Lahir di RSUD Dr. H Abdul Moeloek Bandar Lampung Tahun 2014," Jurnal Kebidanan Malahayati, vol. 2, no. 1, Dec. 2016, Accessed: Jan. 10, 2022. [Online]. Available: http://ejurnalmalahayati.ac.id/index.php/kebidanan/article/view/568/502

[9] Ni Nyoman Ayuk Widiani, Desak Putu Yuli Kurniati, and I Gusti Ayu Trisna Windiani, "Maternal and Infant Risk Factors on The Incidence of Neonatal Asphyxia in Bali: Case

Control Study," Public Health and Preventive Medicine Archive (PHPMA) , vol. 4, no. 2, Dec. 2016, Accessed: Jan. $\quad 2022 . \quad$ [Online]. Available: https://docs.google.com/viewer?url=https://phpmajournal.org/index.php/phpma/article/viewF ile/64/pdf

[10] A. Husna, E. Salmala, M. Marniati, and N. Rahmi, "Faktor-Faktor yang Mempengaruhi terjadinya Asphyxia Neonatorum pada Bayi Baru Lahir yang Dirawat di Rsu Dr Pirngadi Medan Tahun 2007," JOURNAL OF HEALTHCARE TECHNOLOGY AND MEDICINE, vol. 4, no. 2, Oct. 2018, Accessed: Jan. 10, 2022. [Online]. Available: https://jurnal.uui.ac.id/index.php/JHTM/article/view/221/55

[11] M. B. Kurniawan and N. W. Wiwin, "Hubungan Antara Diabetes Melitus Gestasional Dan Berat Badan Lahir Dengan Kejadian Respiratory Distress Syndrome (RDS) Pada Neonatus di RSUD Abdul Wahab Sjahranie Samarinda," Borneo Student Reseach, vol. 1, no. 3, Aug. 2020, Accessed: Jan. 08, 2022. [Online]. Available: https://journals.umkt.ac.id/index.php/bsr/article/view/944/237

[12] R. P. Lumbantoruan, A. Ramadanti, and, Hertanti Indah Lestari, "Hubungan Derajat Asfiksia dengan Kejadian Hipoglikemia pada Neonatus di RSUP Dr. Mohammad Hoesin Palembang," Biomedical Journal of Indonesia, vol. 3, no. 1, Jan. 2017, Accessed: Jan. 10, 2022. [Online]. Available: https://ejournal.unsri.ac.id/index.php/bji/article/download/8590/4590

[13] S. Cnattingius, A. Lindam, and M. Persson, "Risks of asphyxia-related neonatal complications in offspring of mothers with type 1 or type 2 diabetes: the impact of maternal overweight and obesity," Diabetologia, vol. 60, no. 7, pp. 1244-1251, Jul. 2017, doi: 10.1007/s00125-0174279-2.

[14] R. Ahmed et al., "Prevalence and risk factors associated with birth asphyxia among neonates delivered in Ethiopia: A systematic review and metaanalysis," PLOS ONE, vol. 16, no. 8 August. Public Library of Science, Aug. 01, 2021. doi: 10.1371/journal.pone.0255488.

[15] A. Desalew, A. Semahgn, and G. Tesfaye, "Determinants of birth asphyxia among newborns in Ethiopia: A systematic review and meta-analysis," International Journal of Health Sciences, vol. 14, no. 1, Jan. 2020, [Online]. Available: http://www.crd.york.ac.uk/PROSPERO/display

[16] J. S. YANTI, "HUBUNGAN HIPERTENSI KEHAMILAN DENGAN ASFIKSIA NEONATORUM DI RSUD ARIFIN ACHMAD," Jurnal IImiah dan Kajian IImiah Menara IImu, vol. 11, no. 76, Feb. 2017, Accessed: Jan. 07, 2022. [Online]. Available: https://jurnal.umsb.ac.id/index.php/menarailmu/article/view/306

[17] A. G. Dubie, M. Kokeb, A. T. Mersha, and C. D. Agegnehu, "Prevalence and associated factors of perinatal asphyxia in newborns admitted to neonatal intensive care unit at the University of Gondar Comprehensive Specialized Hospital, Northwest Ethiopia, Ethiopia," BMC Pediatrics, vol. 21, no. 1, Dec. 2021, doi: 10.1186/s12887-021-03019-x.

[18] A. Mitha, R. Chen, S. Johansson, N. Razaz, and S. Cnattingius, "Maternal body mass index in early pregnancy and severe asphyxia-related complications in preterm infants," International Journal of Epidemiology, vol. 49, no. 5, pp. 1647-1660, Oct. 2020, doi: 10.1093/ije/dyaa088.

[19] D. Muliawati, E. Sutisna, and U. Retno, "HUBUNGAN RIWAYAT HIPERTENSI DAN PARITAS DENGAN ASFIKSIA NEONATORUM PADA IBU BERSALIN PREEKLAMPSIA BERAT," Jurnal Kesehatan Madani Medika, vol. 7, no. 7, Jun. 2016, Accessed: Jan. 10, 2022. [Online]. Available: https:/jurnalmadanimedika.ac.id/index.php/JMM/article/download/72/39/

[20] M. Persson, S. Johansson, E. Villamor, and S. Cnattingius, "Maternal Overweight and Obesity and Risks of Severe Birth-Asphyxia-Related Complications in Term Infants: A PopulationBased Cohort Study in Sweden," PLoS Medicine, vol. 11, no. 5, 2014, doi: 10.1371/journal.pmed.1001648.

[21] P. Wulandari, A. Arifianto, and F. P. Senjani, "Faktor-Faktor Yang Berhubungan Dengan Kejadian Asfiksia Neonatorum Di Ruang Melati RSUD Dr. H. soewondo Kendal," Journal of 
Holistic Nursing Science, vol. 3, no. 1, Jan. 2017, Accessed: Jan. 10, 2022. [Online]. Available: https://journal.unimma.ac.id/index.php/nursing/article/view/857

[22] K. H. Ahn, E. H. Lee, G. J. Cho, S. C. Hong, M. J. Oh, and H. J. Kim, "Anterior placenta previa in the mid-trimester of pregnancy as a risk factor for neonatal respiratory distress syndrome," PLoS ONE, vol. 13, no. 11, Nov. 2018, doi: 10.1371/journal.pone.0207061.

[23] M. Lankoande et al., "Incidence and outcome of severe ante-partum hemorrhage at the Teaching Hospital Yalgado Ouédraogo in Burkina Faso," BMC Emergency Medicine, vol. 17, no. 1, May 2017, doi: 10.1186/s12873-017-0128-3.

[24] D. Ardyana and E. P. Sari, "HUBUNGAN LILITAN TALI PUSAT, PARTUS LAMA DAN PLASENTA PREVIA DENGAN KEJADIAN ASFIKSIA NEONATORUM," Jurnal 'Aisyiyah Medika, vol. 4, Aug. 2019, Accessed: Jan. 10, 2022. [Online]. Available: https://jurnal.stikesaisyiyah-palembang.ac.id/index.php/JAM/article/view/209

[25] I. B. G. Manuaba, Pengantar Kuliah Obstetri. Jakarta: EGC, 2017.

[26] E. Ekmekci and S. Gencda, "Placental abruption and preterm premature rupture of membranes:How much frequent?," Journal of Clinical and Molecular Medicine, vol. 1, no. 2, 2018, doi: $10.15761 / \mathrm{jcmm} .1000108$.

[27] B. Dinçgez Çakmak, "The Retrospective Analysis of Abruptio Placenta Cases In a Tertiary Center: Risk Factors and Perinatal Outcomes," Haydarpasa Numune Training and Research Hospital Medical Journal, 2018, doi: 10.14744/hnhj.2018.04900.

[28] K. L. Downes, E. D. Shenassa, and K. L. Grantz, "Neonatal Outcomes Associated With Placental Abruption," American Journal of Epidemiology, vol. 186, no. 12, Jun. 2017.

[29] J. Torres-Muñoz, C. Rojas, D. Mendoza-Urbano, D. Marín-Cuero, S. Orobio, and C. Echandía, "Risk factors associated with the development of perinatal asphyxia in neonates at the Hospital Universitario del Valle, Cali, Colombia, 2010-2011," Biomedica, vol. 37, pp. 51-56, Apr. 2017, doi: 10.7705/biomedica.v37i1.2844.

[30] Y. Li, Y. Tian, N. Liu, Y. Chen, and F. Wu, "Analysis of 62 placental abruption cases: Risk factors and clinical outcomes," Taiwanese Journal of Obstetrics and Gynecology, vol. 58, no. 2, pp. 223-226, Mar. 2019, doi: 10.1016/j.tjog.2019.01.010. 